\title{
Tri-functional T cell receptor antigen coupler (Tri-TAC): a novel method to direct T cells against tumors
}

\author{
Christopher Helsen, Ben Li ${ }^{*}$ Galina Denisova, Jonathan L Bramson \\ From Society for Immunotherapy of Cancer 29th Annual Meeting \\ National Harbor, MD, USA. 6-9 November 2014
}

Engineering $\mathrm{T}$ cells with chimeric antigen receptors (CARs) is proving to be an effective method for directing $\mathrm{T}$ cells to attack tumors in an MHC-independent manner. Current generation CARs aim to recapitulate $\mathrm{T}$ cell signaling by incorporating modular functional components of the TCR and costimulatory molecules. Development of next generation CARs has relied upon trial and error evaluation of signaling domains. We sought to develop an alternate method to re-direct the $\mathrm{T}$ cell receptor which does not rely upon the incorporation of signaling domains into the chimeric receptor. To this end, we developed a tri-functional molecule which is membrane-anchored and redirects the TCR in the presence of tumor antigen. We also included components of the $\mathrm{CD} 4$ co-receptor to provide requisite Lck signaling upon ligation of the tumor antigen. Our prototype receptor was directed against the HER-2 proto-oncogene. We have determined that engineering peripheral blood $\mathrm{T}$ cells with this novel receptor (termed a Tri-TAC) engenders tumor-antigen specific activation of numerous $\mathrm{T}$ cell functions, including cytokine production, degranulation and cytolysis - equivalent to, if not greater than, a 2nd generation CAR bearing the CD28 and CD3zeta signaling domains. Future iterations of the engineered $\mathrm{T}$ cells will include chimeric costimulatory receptors to enhance $\mathrm{T}$ cell functionality and reduce off target toxicity. This research was supported by the Canadian Institutes of Health Research and the Terry Fox Foundation.

McMaster University, Hamilton, Ontario, Canada
doi:10.1186/2051-1426-2-S3-P17

Cite this article as: Helsen et al:: Tri-functional T cell receptor antigen coupler (Tri-TAC): a novel method to direct T cells against tumors. Journal for ImmunoTherapy of Cancer 2014 2(Suppl 3):P17.
Submit your next manuscript to BioMed Central and take full advantage of:

- Convenient online submission

- Thorough peer review

- No space constraints or color figure charges

- Immediate publication on acceptance

- Inclusion in PubMed, CAS, Scopus and Google Scholar

- Research which is freely available for redistribution

Submit your manuscript at www.biomedcentral.com/submit
() Biomed Central 